\title{
TRPA1 Is a Component of the Nociceptive Response to $\mathrm{CO}_{2}$
}

\author{
Yuanyuan Y. Wang, Rui B. Chang, and Emily R. Liman \\ Department of Biological Sciences, Section of Neurobiology, University of Southern California, Los Angeles, California 90089
}

In humans, high concentrations of $\mathrm{CO}_{2}$, as found in carbonated beverages, evoke a mixture of sensations that include a stinging or pungent quality. The stinging sensation is thought to originate with the activation of nociceptors, which innervate the respiratory, nasal, and oral epithelia. The molecular basis for this sensation is unknown. Here we show that $\mathrm{CO}_{2}$ specifically activates a subpopulation of trigeminal neurons that express TRPA1, a mustard oil- and cinnamaldehyde-sensitive channel, and that these responses are dependent on a functional TRPA1 gene. TRPA1 is sufficient to mediate responses to $\mathrm{CO}_{2}$ as TRPA1 channels expressed in HEK-293 cells, but not TRPV1 channels, were activated by bath-applied $\mathrm{CO}_{2} \cdot \mathrm{CO}_{2}$ can diffuse into cells and produce intracellular acidification, which could gate TRPA1 channels. Consistent with this mechanism, TRPA1 channels in excised patches were activated in a dose-dependent manner by intracellular protons. We conclude that TRPA1, by sensing intracellular acidification, constitutes an important component of the nociceptive response to $\mathrm{CO}_{2}$.

\section{Introduction}

Humans can sense gaseous $\mathrm{CO}_{2}$, which produces a pungent sensation, as noted more than 100 years ago by the Scottish philosopher Alexander Bain (Cain and Murphy, 1980). Mediating the responses to $\mathrm{CO}_{2}$ in different organisms are a variety of sensory structures and sensory receptors (Luo et al., 2009). For example, in flies, gaseous $\mathrm{CO}_{2}$ is detected by gustatory receptors on the antenna, whereas dissolved $\mathrm{CO}_{2}$ is detected on the proboscis, and $\mathrm{CO}_{2}$ is either aversive or attractive depending on the sensory structure activated (Suh et al., 2004; Fischler et al., 2007; Jones et al., 2007; Kwon et al., 2007). In mice, ingested $\mathrm{CO}_{2}$ is sensed by taste receptors in the mouth (Chandrashekar et al., 2009), and blood $\mathrm{CO}_{2}$ is detected in the brainstem by $\mathrm{K}^{+}$channels (Trapp et al., 2008) and in the amygdala by acid-sensing ion channel (ASIC) 1a (Ziemann et al., 2009), whereas atmospheric levels of $\mathrm{CO}_{2}$ are detected by guanylyl cyclase D (GC-D), which is expressed in a subset of olfactory sensory neurons (Luo et al., 2009). This latter system is missing in humans and most other primates for whom GC-D is a pseudogene (Young et al., 2007).

Although it is widely believed that the noxious sensation of $\mathrm{CO}_{2}$ is due to activation of trigeminal nerve fibers that innervate the nasal and oral cavity (Silver and Moulton, 1982; Steen et al., 1992), the mechanisms by which trigeminal nociceptors detect $\mathrm{CO}_{2}$ remain obscure. Candidates to mediate responses to $\mathrm{CO}_{2}$ include the capsaicin receptor, TRPV1, which is expressed in trigeminal and dorsal root ganglia and activated by extracellular protons (Caterina et al., 1997; Tominaga et al., 1998), and the ASICs, which are widely distributed (Waldmann and Lazdunski,

Received May 26, 2010; revised July 22, 2010; accepted July 30, 2010.

This work was supported by National Institutes of Health Grant DC004564 to E.R.L. We thank H. Waters for technical support, D. Corey for providing mice, D. McKemy and R. Daniels for advice in preparing neuronal cultures, and D. Arnold and D. McKemy for careful reading of the manuscript.

This article is freely available online through the J Neurosci Open Choice option.

Correspondence should be addressed to Dr. Emily R. Liman, Department of Biological Sciences, Section of Neurobiology, University of Southern California, 3641 Watt Way, Los Angeles, CA 90089-2520. E-mail: Liman@usc.edu. DOI:10.1523/JNEUROSCI.2715-10.2010

Copyright $\odot 2010$ the authors $\quad 0270-6474 / 10 / 3012958-06 \$ 15.00 / 0$
1998); however, the response of sensory nerve fibers to $\mathrm{CO}_{2}$ is distinct from the response to extracellular protons, suggesting the participation of other receptors (Steen et al., 1992; Simons et al., 1999). Another candidate is the "wasabi receptor" TRPAl, which forms a cation channel expressed by a subset of TRPV1-containing neurons (Bautista et al., 2006; Bandell et al., 2007). Agents that activate TRPA1 include plant products such as mustard oil and cinnamaldehyde (Cin), industrial products such as formaldehyde and acrolein, and products of oxidative stress (Patapoutian et al., 2009). The observation that $\mathrm{CO}_{2}$ evokes a sensation that is described as painful suggests TRPA1 may also mediate responses to this gas.

\section{Materials and Methods}

Animals. All experimental procedures were approved by the Institutional Animal Care and Use Committee of the University of Southern California. Mice were derived from crosses of TRPA1 ${ }^{-1-}$ (B6;129P-

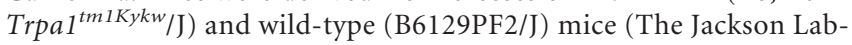
oratory) and were genotyped by PCR.

Cultures of trigeminal ganglion neurons. Trigeminal ganglion neurons were dissociated from postnatal $2 \sim 6$-week-old mice as previously described (Takashima et al., 2007). In brief, the isolated trigeminal ganglia from two mice were dissected and sequentially incubated in $0.25 \%$ collagenase type I for $\sim 30 \mathrm{~min}$ at $37^{\circ} \mathrm{C}$ and in $0.05 \%$ trypsin for $1 \mathrm{~min}$ at $37^{\circ} \mathrm{C}$. The isolated cells were plated onto six to 12 glass coverslips coated with Matrigel and incubated at $37^{\circ} \mathrm{C}$ for $24-48 \mathrm{~h}$ in culture media supplemented with $100 \mathrm{ng} / \mathrm{ml}$ NGF. Data shown represent the results from three to six cultures from 6 to 12 mice.

cDNAs and expression in HEK-293 cells. A yellow fluorescent protein (YFP) fusion of rat TRPA1 (Wang et al., 2008) was transiently transfected into HEK-293 cells using TransIT-LT1 transfection reagent (Mirus Bio). For excised-patch recording, we used native rat TRPAl cotransfected with green fluorescent protein (GFP; 20:1). Recordings or $\mathrm{Ca}^{2+}$ imaging experiments were performed $\sim 24-48 \mathrm{~h}$ after transfection at room temperature.

$\mathrm{Ca}^{2+}$ imaging. Measurement of agonist-induced changes in intracellular $\mathrm{Ca}^{2+}$ was as previously described (Zhang et al., 2007). In brief, cells were loaded with fura-2 $\mathrm{AM}$ and $\mathrm{Ca}^{2+}$ levels were measured from the ratio of emission in response to excitation at 340 and $380 \mathrm{~nm}$. All cells showed nonspecific responses to $\mathrm{CO}_{2}$ [average of 0.15 arbitrary unit 

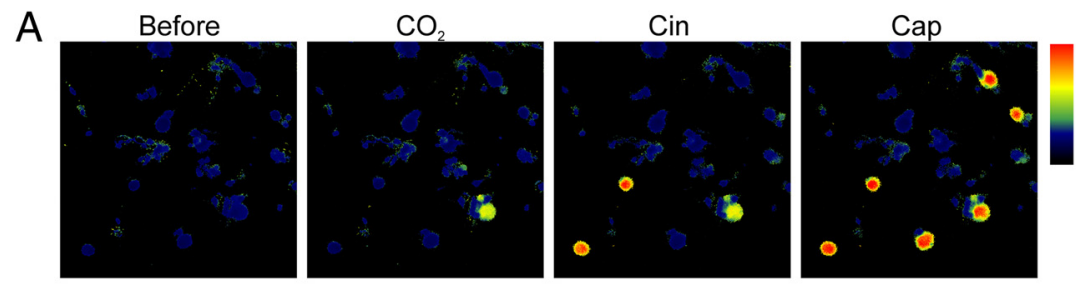

B
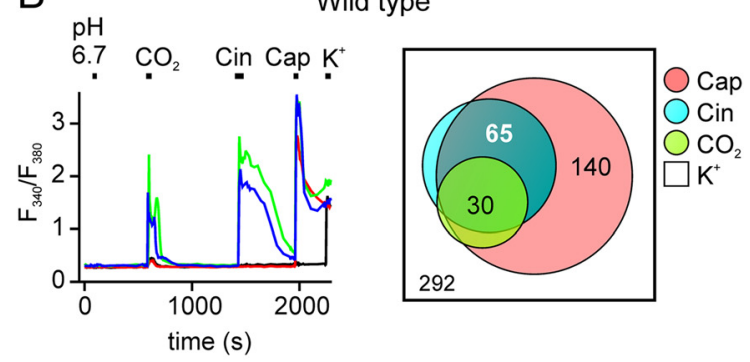

D

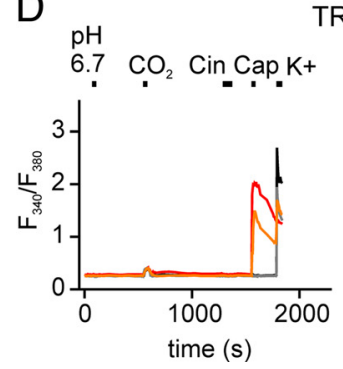

TRPA1 -/-
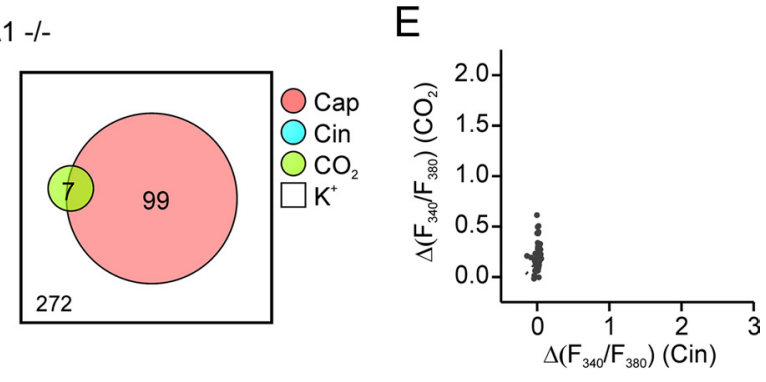

Figure 1. Responses of trigeminal sensory neurons to carbon dioxide. $\boldsymbol{A}$, Agonist responses of cultured trigeminal sensory neurons from wild-type mice measured with ratiometric calcium imaging. Scale is from 0 to 2.3 AU. $B, D$, Time course of the agonist responses of representative trigeminal neurons isolated from wild-type or TRPA1 ${ }^{-/-}$animals. A subpopulation of trigeminal neurons from wild-type mice responded to $\mathrm{CO}_{2}$ and to the TRPA1 agonist $\mathrm{Cin}(100 \mu \mathrm{M})$ and the TRPV1 agonist $\mathrm{Cap}(1 \mu \mathrm{M})(\boldsymbol{B}$, green and blue traces). In contrast, in cultures from TRPA1 ${ }^{-1-}$ mice, few cells responded to $\mathrm{CO}_{2}$ and none responded to $\mathrm{Cin}$, whereas responses to Cap were maintained ( $\boldsymbol{D}$, orange and red traces). Venn diagrams show the aggregate results from all experiments. Numbers represent the total count of the responsive cells to each agonist, and overlap and size of each circle is drawn to scale. $\boldsymbol{C}, \boldsymbol{E}$, Scatter plot of the magnitude of the response to $\mathrm{CO}_{2}$ as a function of the response to $\operatorname{cin}$ from the experiment as in $\boldsymbol{B}$ and $\boldsymbol{D}$, respectively. $r=0.625$ for fit to data in $\boldsymbol{C}$.

(AU)] (supplemental Fig. 1, available at www.jneurosci.org as supplemental material), which may be attributed to effects of intracellular acidification on emission by the dye or on $\mathrm{Ca}^{2+}$ handling (Martínez-Zaguilán et al., 1996). Responses were, therefore, categorized as positive if the change in $F_{(340)} / F_{(380)}$ after application of agonist was $>0.33 \mathrm{AU}, 4$ SDs higher than the average nonspecific response. The same threshold was applied to all agonists and all conditions. Venn diagrams were drawn using Venn Diagram Plotter (PNNL; http://omics.pnl.gov).

Patch-clamp recording. Patch-clamp electrophysiology was performed as previously described (Liu and Liman, 2003; Zhang et al., 2007). For whole-cell recordings, the membrane potential was held at $-80 \mathrm{mV}$ and ramped from $-80 \mathrm{mV}$ to $80 \mathrm{mV}(1 \mathrm{~V} / \mathrm{s})$. Extracellular solution was exchanged either by gravity flow through the chamber (for experiments in which responses to $\mathrm{CO}_{2}$ were measured) or by placing the cell or patch in front of a linear array of microperfusion pipes that were moved under computer control (for block by extracellular protons and excised patch experiments; Warner Instruments). For most experiments, responses were quantified as the change in the magnitude of the current compared with current immediately before agonist delivery. Excised-patch recording was as described previously (Liu and Liman, 2003): following formation of a gigaohm seal, the patch was excised into $\mathrm{Ca}^{2+}$-free solution and positioned in front of the microperfusion pipes.

Solutions. For $\mathrm{Ca}^{2+}$ imaging experiments, the bath solution contained the following (in mM): $145 \mathrm{NaCl}, 10 \mathrm{HEPES}, 5 \mathrm{KCl}, 20$ glucose, $1 \mathrm{MgCl}_{2}$, $2 \mathrm{CaCl}_{2}, \mathrm{pH} 7.4$ or $\mathrm{pH} 6.75$ as indicated. $\mathrm{CO}_{2}(100 \%)$ was bubbled into the following (in mM): $100 \mathrm{NaHCO}_{3}, 50 \mathrm{NaCl}, 1.25 \mathrm{NaH}_{2} \mathrm{PO}_{4}, 2.5 \mathrm{KCl}$, 25 glucose, $1 \mathrm{MgCl}_{2}, 2 \mathrm{CaCl}_{2}, \mathrm{pH} 6.75$ with $\mathrm{CO}_{2}$. High $\mathrm{K}^{+}$solution contained the following (in $\mathrm{mm}$ ): $150 \mathrm{KCl}, 2$ $\mathrm{CaCl}_{2}, 10$ HEPES, pH 7.4. For whole-cell patch-clamp recordings, the bath solution was as follows (in $\mathrm{mm}$ ): $150 \mathrm{NaCl}, 2 \mathrm{CaCl}_{2}, 10$ HEPES, $\mathrm{pH}$ 7.4. $\mathrm{CO}_{2}$ was bubbled into this solution ( $\mathrm{pH}$ 5.3-5.4 with $\mathrm{CO}_{2}$ ) as indicated. Bicarbonate buffered saline contained the following (in mM): $25 \mathrm{NaHCO}_{3}, 125 \mathrm{NaCl}, 25$ glucose, $2.5 \mathrm{KCl}, 1.25 \mathrm{NaH}_{2} \mathrm{PO}_{4}, 2 \mathrm{CaCl}_{2}, 1$ $\mathrm{MgCl}_{2}, \mathrm{pH} 7.4 ; \mathrm{pH} 5.9$ with $\mathrm{CO}_{2}$. Internal solution contained the following (in $\mathrm{mM}$ ): 145 $\mathrm{CsCl}, 5$ EGTA, $10 \mathrm{HEPES}$, with $3 \mathrm{CaCl}_{2}$ (100 $\mathrm{nm}$ free $\mathrm{Ca}^{2+}$ ) and $2 \mathrm{MgATP}, \mathrm{pH} 7.4$ with $\mathrm{CsOH}$. To exclude the possibility that the observed effects were due to release of $\mathrm{Ca}^{2+}$ from the chelator in response to intracellular acidification, in some experiments $\mathrm{Ca}^{2+}$ and MgATP were excluded from the internal solution (as indicated). $\mathrm{Ca}^{2+}$ free-bath solution contained the following (in mM): $150 \mathrm{NaCl}, 0.5$ EGTA, with 10 HEPES, $\mathrm{pH}$ 7.4. Acidic solutions contained $150 \mathrm{~mm} \mathrm{NaCl}, 0.5 \mathrm{~mm}$ EGTA, and $10 \mathrm{~mm}$ MES, pH 3-6. For excised-patch experiments, the pipette solution was $150 \mathrm{~mm} \mathrm{NaCl}, 0.5 \mathrm{~mm}$ EGTA, with 10 mm HEPES, pH 7.4. Solution applied to the cytoplasmic side of the cell contained $150 \mathrm{~mm} \mathrm{KCl,} 0.5 \mathrm{~mm}$ EGTA, 1 mm pentasodium tripolyphosphate hexahydrate ( polyP $_{3}$ ) buffered with either $10 \mathrm{~mm}$ HEPES, pH 7.4, 9.5, or 5.5 (supplemental Fig. 3, available at www. jneurosci.org as supplemental material) or $10 \mathrm{~mm}$ MES, pH 6.5-4.5.

Chemicals. Cinnamaldehyde, capsaicin, and polyP $\mathrm{P}_{3}$ were purchased from Sigma. Fura-2, collagenase type I, DMEM, F-12, trypsin, and gentamicin were from Invitrogen. $\mathrm{N}$-(4Tertiarybutylphenyl)-4-(3-chloropyridin-2yl)tetrahydropyrazine- $1(2 H)$-carboxamide (BCTC) was from Biomol. Matrigel was from BD Biosciences.

Data analysis. When comparing numbers of responsive cells, Pearson's $\chi^{2}$ test was used; otherwise Student's $t$ test was used.

\section{Results}

To identify mechanisms by which nociceptors respond to $\mathrm{CO}_{2}$, we measured agonist responses in cultured trigeminal sensory neurons using ratiometric $\mathrm{Ca}^{2+}$ imaging. A subset of neurons (30 of 292) responded strongly to extracellular solution bubbled with $\mathrm{CO}_{2}$ but not to a control solution at the same $\mathrm{pH}(\mathrm{pH}$ 6.75) (Fig. $1 A, B)$; these cells were classified as $\mathrm{CO}_{2}$-sensitive. Because all cells showed nonspecific responses to $\mathrm{CO}_{2}$ (Martínez-Zaguilán et al., 1996), for this analysis, responses were only counted as positive if the change in the emission ratio exceeded $0.33 \mathrm{AU}$, a value chosen as 4 SDs higher than the average nonspecific response (see Materials and Methods) (supplemental Fig. 1, available at www. jneurosci.org as supplemental material). The same criterion was applied to all cells and all agonists. Nearly all $\mathrm{CO}_{2}$-sensitive cells responded to a later application of the TRPA1 agonist Cin (100 $\mu \mathrm{M} ; 25$ of 30 cells) and to the TRPV1 agonist capsaicin (Cap; 1 $\mu \mathrm{M} ; 29$ of 30 cells) (Fig. $1 \mathrm{~B}$ ). Overall, $\mathrm{CO}_{2}$-responsive cells were highly enriched in the population of Cin-responsive cells compared with the population of all electrically responsive cells ( 25 of 65 compared with 30 of $\left.292 ; \chi^{2}, p<0.0001\right)$ and the magnitudes of the responses of individual cells to $\mathrm{CO}_{2}$ were correlated with the magnitudes of the responses of the same cells to $\mathrm{Cin}(r=$ $0.625, p<0.001$ ) (Fig. 1C). $\mathrm{CO}_{2}$-responsive cells were also en- 
A TRPA1
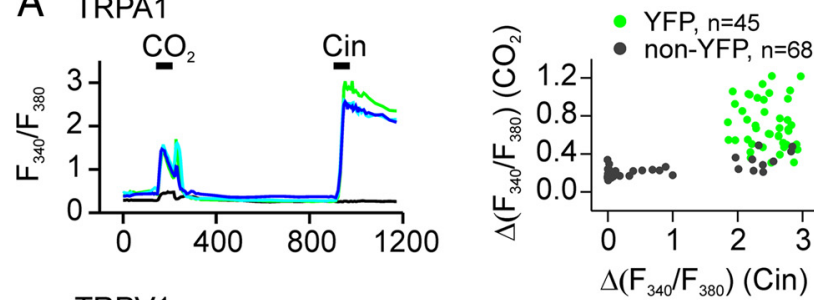

TRPV1

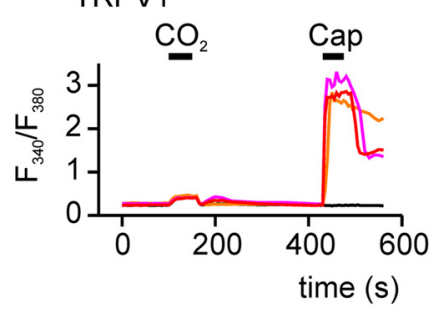

B

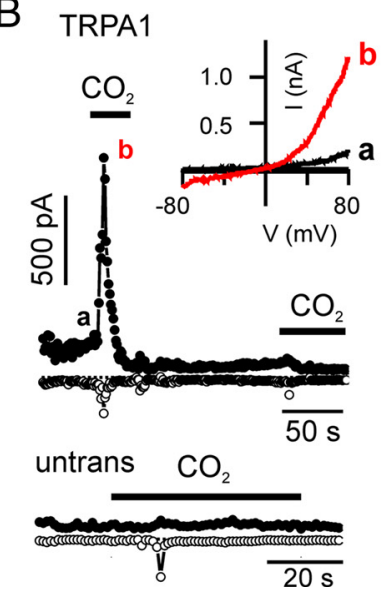

C
A

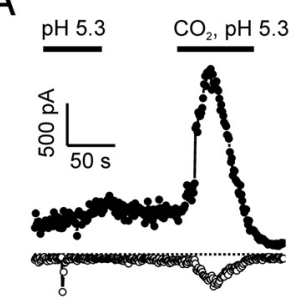

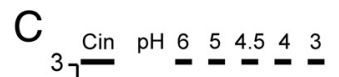
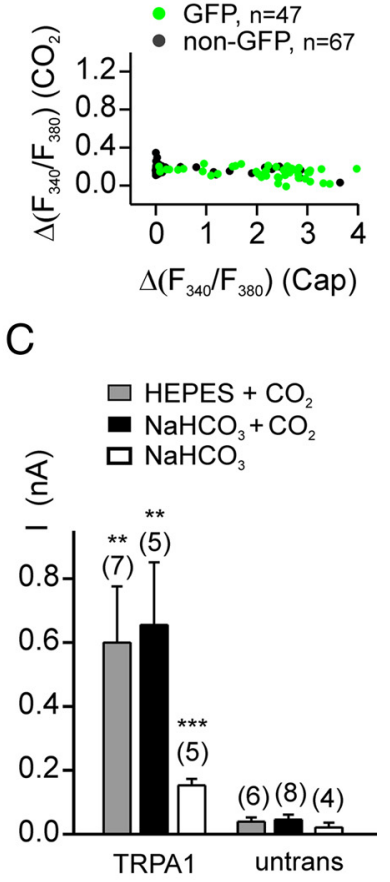
$n=0.91$.
B

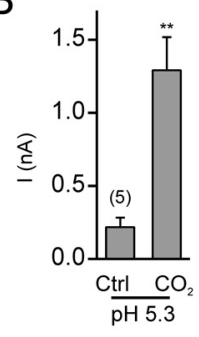

D

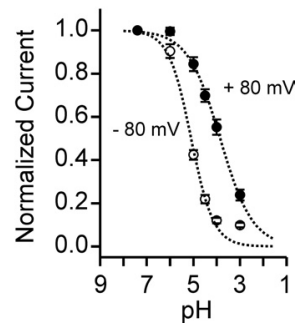

Figure 3. TRPA1 channels are blocked by extracellular protons. $\boldsymbol{A}$, Whole-cell currents in HEK-293 cells expressing TRPA1 were activated by $\mathrm{CO}_{2}$ in HEPES-buffered saline, $\mathrm{pH}$ 5.3, but not by extracellular acidification alone, $\mathrm{pH}$ 5.3. The small inward current in response to the $\mathrm{pH} 5.3$ solution represents the endogenous ASIC current. Both the internal and external solution were $\mathrm{Ca}^{2+}$-free. $\boldsymbol{B}$, Average peak outward current (at $80 \mathrm{mV}$ ) from experiments as in $\boldsymbol{A}$. Data are represented by the mean \pm SEM. ${ }^{* *} p<0.01$ (two-tailed Student's $t$ test). C, TRPA 1 currents activated by Cin $(100 \mu \mathrm{M})$ were blocked in a dose-dependent manner by extracellular acidification. $\mathrm{Ca}^{2+}$ was omitted from the extracellular solution to prevent inactivation. $\boldsymbol{D}$, Dose dependence of proton block of TRPA1 currents from experiments as shown in $\boldsymbol{A}$ $(n=7)$. For currents at $V_{\mathrm{m}}=80 \mathrm{mV}$, the data were fit was with a Hill equation with $V_{\max }=1, \mathrm{~K}_{1 / 2}=$ $140 \mu \mathrm{m}, n=0.62$. For currents at $V_{\mathrm{m}}=-80 \mathrm{mV}$, the data were fit with $V_{\max }=1, \mathrm{~K}_{1 / 2}=8.04 \mu \mathrm{m}$,

were mediated instead by TRPA1, we repeated the experiment with trigeminal neurons isolated from TRPA1 knock-out animals (Fig. 1D,E) (Kwan et al., 2006). Responses to $\mathrm{CO}_{2}$ were largely absent from these cultures, indicating that a functional TRPA1 gene is required for $\mathrm{CO}_{2}$ sensitivity of trigeminal sensory neurons ( 7 of 272 cells compared with $30 / 292 ; \chi^{2}, p<0.001$ ). It should be noted that the residual $\mathrm{CO}_{2}$ responses in these cultures were on average smaller than responses in Cin-sensitive cells from wildtype cultures $(0.46 \pm 0.03$ vs $0.80 \pm 0.073 \mathrm{AU} ; p<0.05$, onetailed Mann-Whitney $U$ test); they may represent either nonspecific responses that escaped our threshold or a TRPA1independent $\mathrm{CO}_{2}$-sensing mechanism.

We next asked whether TRPAl could be activated by $\mathrm{CO}_{2}$. HEK-293 cells transfected with TRPA1 generated robust responses to $\mathrm{CO}_{2}$ as measure by $\mathrm{Ca}^{2+}$ imaging (43 of 45 YFPpositive cells) (Fig. $2 A$ ); similar responses were not observed in either untransfected or TRPV1-transfected cells ( 0 of 183 and 0 of 47 GFP-positive cells responded, respectively; $\chi^{2} p<0.0001$ for both compared with the response of TRPA1 transfected cells) (Fig. 2A). Interestingly, the response of TRPA1-transfected cells to $\mathrm{CO}_{2}$ showed the same biphasic time course as did the response of native cells (compare Figs. $2 A, 1 B$ ). In whole-cell patch-clamp recording, bath-applied $\mathrm{CO}_{2}$ bubbled into HEPES or bicarbonate-buffered saline elicited large currents in TRPA1transfected, but not in untransfected, HEK-293 cells (Fig. 2B,C). The $\mathrm{CO}_{2}$-activated current in TRPA1-expressing cells reversed at $-5.74 \pm 1.30 \mathrm{mV}(n=7)$, as expected for a nonselective cation channel, and showed strong outward rectification $\left(-\mathrm{I}_{80} / \mathrm{I}_{-80}=\right.$ $9.47 \pm 2.18, n=7)$. Following activation in response to $\mathrm{CO}_{2}$, TRPAl currents rapidly inactivated. Additional responses could 
A
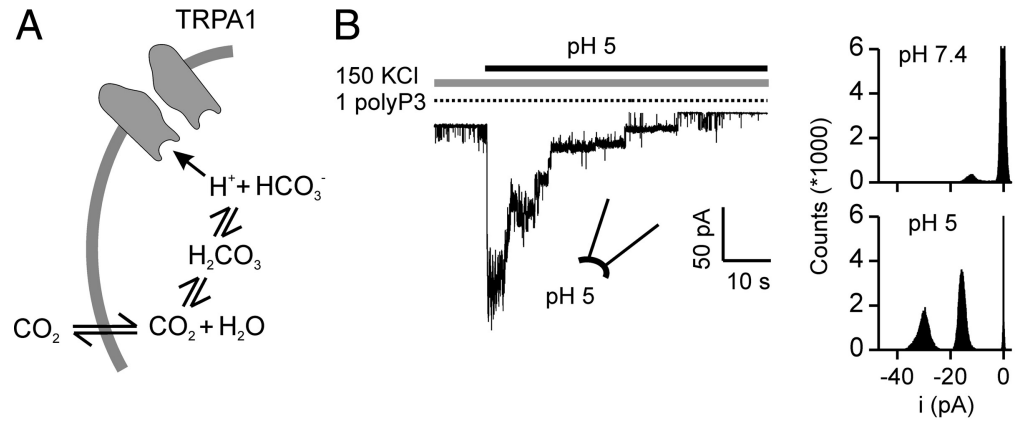

C
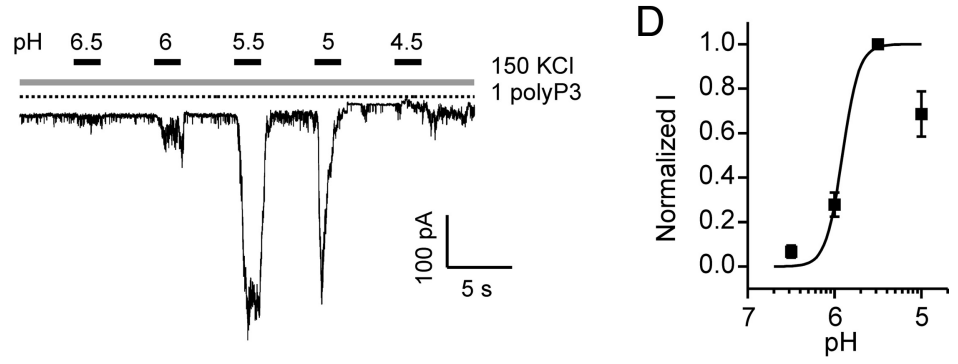

E

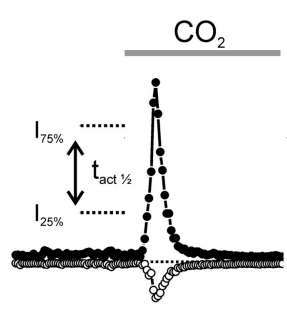

$0.01 \mathrm{mM}$ HEPES

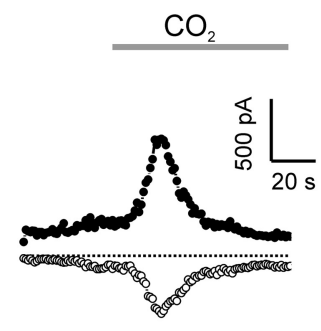

100 mM HEPES
$\mathrm{F}$

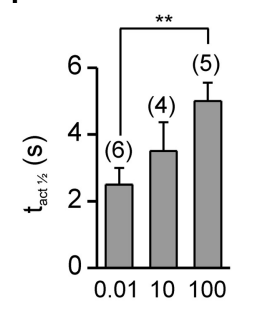

Figure 4. Carbon dioxide activates TRPA1 through intracellular acidification. $\boldsymbol{A}$, Model for activation of TRPA1 by $\mathrm{CO}_{2}$. B Channel activity in an inside-out patch from a HEK-293 cell transfected with TRPA1 in response to cytoplasmic solution of pH 5 (1 mм poly $P_{3}$ to retain channel activity; $V_{m}=-80 \mathrm{mV}$ ) (Kim and Cavanaugh, 2007). All points histogram shows the amplitude of the response. C, Current activation $\left(V_{\mathrm{m}}=-80 \mathrm{mV}\right)$ in response to increasing concentrations of protons (buffered by $10 \mathrm{~mm}$ MES, in the presence of $1 \mathrm{~mm}$ polyP3) in an inside-out patch. $\boldsymbol{D}$, Dose-response curve for activation of TRPA1 currents by intracellular protons from experiments as in C. Data were normalized to the current at pH 5.5 in each patch. Fit was with $V_{\max }=1, \mathrm{~K}_{1 / 2}=1.23 \mu \mathrm{M}, n=$ 4.55. Data are represented by the mean $\pm S E M, n=12$. $E$, Responses to $\mathrm{CO}_{2}$ (bubbled into HEPES-buffered saline) from TRPA1expressing HEK-293 cells in whole-cell recording with a pipette solution containing $10 \mu \mathrm{m}$ HEPES (left) or $100 \mathrm{~mm}$ HEPES (right). $\boldsymbol{F}$, Average data from experiments as in $\boldsymbol{E}$, showing the half-activation time (time from $25 \%$ to $75 \%$ of the peak outward current; right). Data are represented by the mean \pm SEM. ${ }^{* *} p<0.01$ (two-tailed Student's $t$ test).

not be evoked by $\mathrm{CO}_{2}$ during the time period of the recording $(n=4)$ (Fig. $2 B)$. Currents of similar magnitude and inactivation kinetics were activated regardless of whether the intracellular solution contained a physiological concentration of $\mathrm{Ca}^{2+}$ or was $\mathrm{Ca}^{2+}$-free $(\mathrm{I}=1.2 \pm 0.1 \mathrm{nA}, n=6$ vs $2.3 \pm 0.5 \mathrm{nA}, n=7$, respectively; $p=0.1$; inactivation $t_{1 / 2}=2.8 \pm 0.4 \mathrm{~s}, n=6$ vs $t_{1 / 2}=$ $3.8 \pm 0.8 \mathrm{~s}, n=6$, respectively; $p=0.3$ ), indicating that activation of TRPA1 by $\mathrm{CO}_{2}$ was not mediated by elevation of intracellular $\mathrm{Ca}^{2+}$ (Wang et al., 2008). The observations that currents of similar magnitudes were activated when $\mathrm{CO}_{2}$ was bubbled into HEPES and bicarbonate-buffered solutions (Fig. 2C), and currents of a smaller magnitude were evoked in response to the bicarbonate solution alone (Fig. $2 \mathrm{C}$ ), indicate that the responses could not be attributed to a direct effect of the extracellular bicarbonate ion. The small response evoked by the bicarbonate solution alone can be attributed to the low concentration of $\mathrm{CO}_{2}$ at equilibrium in this solution $(\sim 2 \mathrm{~mm}$ compared with $\sim 33 \mathrm{mM}$ in the $\mathrm{CO}_{2}$-saturated solutions).

To determine whether responses of TRPA1 to $\mathrm{CO}_{2}$ could be attributed to gating of the channel by extracellular protons, we tested
HEPES (mM)

whether extracellular acidification alone could activate TRPA1 currents. Extracellular solution of $\mathrm{pH} 5.3$ elicited no response in TRPA1-transfected cells, although these cells responded to a subsequent application of $\mathrm{CO}_{2}$ (in HEPES-buffered saline, $\mathrm{pH}$ 5.3) (Fig. 3A,B). Interestingly, more severe extracellular acidification had a blocking effect on Cin-activated TRPA1 currents (Fig. 3C,D).

How does $\mathrm{CO}_{2}$ activate TRPA1? $\mathrm{CO}_{2}$ can freely diffuse into cells where it re-equilibrates to generate bicarbonate $\left(\mathrm{HCO}_{3}^{-}\right)$and a free proton $\left(\mathrm{H}^{+}\right)$, causing acidification of the cell cytosol that can reach as low as $\mathrm{pH} 6$ for $100 \% \mathrm{CO}_{2}$ at atmospheric pressure (Fig. 4A) (Caldwell, 1958). To determine whether elevation of intracellular protons is sufficient to activate TRPA1, we measured responses in excised patches to changes in cytoplasmic $\mathrm{pH}$. In patches from HEK-293 cells transfected with TRPA1, a cytoplasmic solution adjusted to $\mathrm{pH} 5$ strongly activated TRPA1 channels, which had a unitary current of $-14.1 \pm 0.3 \mathrm{pA}$ at $-80 \mathrm{mV}(n=9$; 9 of 16 patches responded) (Fig. $4 B$ ). No channels were activated in patches from untransfected cells $(n=3)$. Channel activity showed inactivation in the continued presence of the acidic solution, similar to the inactivation observed in whole-cell recording (Fig. 4B). Responses of TRPA1 channels to intracellular protons were dose-dependent (Fig. 4C,D). Activation could be observed beginning at $\mathrm{pH} 6.5$ and reached a maximum at approximately $\mathrm{pH}$ 5.5. As compared with the response to acidic solutions, alkaline solutions, $\mathrm{pH}$ 9.5, produced no detectable activation (supplemental Fig. 3, available at www.jneurosci.org as supplemental material) (Fujita et al., 2008; Dhaka et al., 2009).

If a change in the concentration of intracellular protons contributes to the activation of TRPA1 by $\mathrm{CO}_{2}$, then strongly buffering intracellular $\mathrm{pH}$ should affect the response. Indeed, activation of TRPA1 by $\mathrm{CO}_{2}$ was significantly slowed under conditions in which the intracellular $\mathrm{pH}$ was strongly buffered (100 mM HEPES) compared with when it was weakly buffered (0.01 mM HEPES) (Fig. 4E, F). These data indicate that intracellular protons gate TRPA1, either by binding directly to the channel, or by interacting with closely associated molecules (Fig. 4A).

\section{Discussion}

Our results show that the ion channel TRPA1 is both necessary and sufficient to mediate responses of trigeminal sensory neurons to $\mathrm{CO}_{2}$ and that activation of TRPA1 is downstream of intracellular acidification. Although ion channels such as ASIC and TRPV1, which respond to extracellular acidification and are expressed by nociceptors, have been well described (Waldmann and Lazdunski, 1998; Caterina and Julius, 2001), a specific sensor within nociceptors for intracellular acidification has not been 
reported. Moreover, our data argue against a specific contribution of the capsaicin receptor TRPV1 to the trigeminal response to $\mathrm{CO}_{2}$, as we observed neither a significant decrease in the response of sensory neurons to $\mathrm{CO}_{2}$ following block of TRPV1 nor an activation of heterologously expressed TRPV1 by application of $\mathrm{CO}_{2}$. It is nonetheless possible, that under natural conditions, the extracellular acidification that accompanies $\mathrm{CO}_{2}$ exposure could recruit cells that express only TRPV1.

Our report is one of the first descriptions of a nonspecific cation channel that is gated by intracellular protons. A previous study showed that protons delivered in the extracellular solution could activate TRPA1 (Takahashi et al., 2008). However, in this study, which was done solely with $\mathrm{Ca}^{2+}$ imaging, it was not determined whether protons act on an extracellular site on TRPA1 or enter the cell and act on an intracellular site. Our data with excised patches show that intracellular protons, at a concentration as low as $1 \mu \mathrm{M}$, can directly activate TRPA 1 channels. Interestingly, it was recently found that the fly phototransduction channel, dTRP, which is distantly related to TRPA1, is gated by cytosolic acidification, and this may be the mechanism for activation of this channel by the phototransduction cascade (Huang et al., 2010). Several two-pore domain $\mathrm{K}^{+}$ channels are activated by intracellular acidosis, including TREK2, which is expressed by DRG neurons (Patel and Honoré, 2001; Kang and Kim, 2006). However, these channels inhibit electrical activity under conditions of cellular acidosis, and thus are unlikely to contribute to the excitatory sensory response to $\mathrm{CO}_{2}$.

Our data show that acidification has two opposing effects on TRPA1. From the inside, protons activate TRPA1, and from the outside, they block channel activity. Interestingly, TRPV1 shows the opposite response to protons; it is activated by extracellular acidification and by intracellular alkalinization (Dhaka et al., 2009). Block by extracellular acidification would be expected to dampen TRPA1-mediated pain response under conditions of tissue acidosis; however, the extremely low $\mathrm{pH}$ levels required to observe block of TRPA1 ( $<\mathrm{pH} 5)$ may never be attained in intact tissues (Bevan and Geppetti, 1994). We did not observe significant activation of TRPA 1 channels in excised patches in response to solutions of basic $\mathrm{pH}, \mathrm{pH} 9.5$, contrary to a previous report suggesting that responses to ammonia, which produces intracellular alkalinization, were mediated by TRPA1 (Fujita et al., 2008). However, a more recent report provides evidence that TRPV1, not TRPA1, is the primary target for ammonia (Dhaka et al., 2009).

Together with other recent reports, our data highlight the diversity of sensory systems and cellular mechanisms within vertebrates for the detection of $\mathrm{CO}_{2}$. These include the olfactory system, where a subset of GC-D-expressing cells respond to $\mathrm{CO}_{2}$ (Luo et al., 2009), the taste system, for which $\mathrm{CO}_{2}$ evokes a sour sensation mediated by PKD2L1-expressing taste cells (Chandrashekar et al., 2009), and the trigeminal system, where, according to our data, TRPA1 contributes to the noxious response. In addition, there are at least two central systems that detect elevated levels of $\mathrm{CO}_{2}$ in the bloodstream: the brainstem, which controls ventilatory responses, and the amygdala, which controls fear responses (Trapp et al., 2008; Ziemann et al., 2009). How these systems work together to create the distinct sensations and behaviors elicited by $\mathrm{CO}_{2}$ can now be investigated by genetically manipulating each of these systems alone and in combination.

\section{References}

Bandell M, Macpherson LJ, Patapoutian A (2007) From chills to chilis: mechanisms for thermosensation and chemesthesis via thermoTRPs. Curr Opin Neurobiol 17:490-497.

Bautista DM, Jordt SE, Nikai T, Tsuruda PR, Read AJ, Poblete J, Yamoah EN, Basbaum AI, Julius D (2006) TRPA1 mediates the inflammatory actions of environmental irritants and proalgesic agents. Cell 124:1269-1282.

Bevan S, Geppetti P (1994) Protons: small stimulants of capsaicin-sensitive sensory nerves. Trends Neurosci 17:509-512.

Cain WS, Murphy CL (1980) Interaction between chemoreceptive modalities of odour and irritation. Nature 284:255-257.

Caldwell PC (1958) Studies on the internal pH of large muscle and nerve fibres. J Physiol 142:22-62.

Caterina MJ, Julius D (2001) The vanilloid receptor: a molecular gateway to the pain pathway. Annu Rev Neurosci 24:487-517.

Caterina MJ, Schumacher MA, Tominaga M, Rosen TA, Levine JD, Julius D (1997) The capsaicin receptor: a heat-activated ion channel in the pain pathway. Nature 389:816-824.

Chandrashekar J, Yarmolinsky D, von Buchholtz L, Oka Y, Sly W, Ryba NJ, Zuker CS (2009) The taste of carbonation. Science 326:443-445.

Dhaka A, Uzzell V, Dubin AE, Mathur J, Petrus M, Bandell M, Patapoutian A (2009) TRPV1 is activated by both acidic and basic pH. J Neurosci 29:153-158.

Fischler W, Kong P, Marella S, Scott K (2007) The detection of carbonation by the Drosophila gustatory system. Nature 448:1054-1057.

Fujita F, Uchida K, Moriyama T, Shima A, Shibasaki K, Inada H, Sokabe T, Tominaga M (2008) Intracellular alkalization causes pain sensation through activation of TRPA1 in mice. J Clin Invest 118:4049-4057.

Huang J, Liu CH, Hughes SA, Postma M, Schwiening CJ, Hardie RC (2010) Activation of TRP channels by protons and phosphoinositide depletion in Drosophila photoreceptors. Curr Biol 20:189-197.

Jones WD, Cayirlioglu P, Kadow IG, Vosshall LB (2007) Two chemosensory receptors together mediate carbon dioxide detection in Drosophila. Nature 445:86-90.

Kang D, Kim D (2006) TREK-2 (K2P10.1) and TRESK (K2P18.1) are major background $\mathrm{K}+$ channels in dorsal root ganglion neurons. Am J Physiol Cell Physiol 291:C138-C146.

Kim D, Cavanaugh EJ (2007) Requirement of a soluble intracellular factor for activation of transient receptor potential A1 by pungent chemicals: role of inorganic polyphosphates. J Neurosci 27:6500-6509.

Kwan KY, Allchorne AJ, Vollrath MA, Christensen AP, Zhang DS, Woolf CJ, Corey DP (2006) TRPAl contributes to cold, mechanical, and chemical nociception but is not essential for hair-cell transduction. Neuron 50:277-289.

Kwon JY, Dahanukar A, Weiss LA, Carlson JR (2007) The molecular basis of $\mathrm{CO} 2$ reception in Drosophila. Proc Natl Acad Sci U S A 104:3574-3578.

Liu D, Liman ER (2003) Intracellular Ca2 + and the phospholipid PIP2 regulate the taste transduction ion channel TRPM5. Proc Natl Acad Sci U S A 100:15160-15165.

Luo M, Sun L, Hu J (2009) Neural detection of gases-carbon dioxide, oxygen-in vertebrates and invertebrates. Curr Opin Neurobiol 19:354-361.

Martínez-Zaguilán R, Gurulé MW, Lynch RM (1996) Simultaneous measurement of intracellular $\mathrm{pH}$ and $\mathrm{Ca} 2+$ in insulin-secreting cells by spectral imaging microscopy. Am J Physiol 270:C1438-C1446.

Patapoutian A, Tate S, Woolf CJ (2009) Transient receptor potential channels: targeting pain at the source. Nat Rev Drug Discov 8:55-68.

Patel AJ, Honoré E (2001) Properties and modulation of mammalian 2P domain K+ channels. Trends Neurosci 24:339-346.

Silver WL, Moulton DG (1982) Chemosensitivity of rat nasal trigeminal receptors. Physiol Behav 28:927-931.

Simons CT, Dessirier JM, Carstens MI, O’Mahony M, Carstens E (1999) Neurobiological and psychophysical mechanisms underlying the oral sensation produced by carbonated water. J Neurosci 19:8134-8144.

Steen KH, Reeh PW, Anton F, Handwerker HO (1992) Protons selectively induce lasting excitation and sensitization to mechanical stimulation of nociceptors in rat skin, in vitro. J Neurosci 12:86-95.

Suh GS, Wong AM, Hergarden AC, Wang JW, Simon AF, Benzer S, Axel R, Anderson DJ (2004) A single population of olfactory sensory neurons mediates an innate avoidance behaviour in Drosophila. Nature 431:854-859. 
Takahashi N, Mizuno Y, Kozai D, Yamamoto S, Kiyonaka S, Shibata T, Uchida K, Mori Y (2008) Molecular characterization of TRPA1 channel activation by cysteine-reactive inflammatory mediators. Channels (Austin) 2:287-298.

Takashima Y, Daniels RL, Knowlton W, Teng J, Liman ER, McKemy DD (2007) Diversity in the neural circuitry of cold sensing revealed by genetic axonal labeling of transient receptor potential melastatin 8 neurons. J Neurosci 27:14147-14157.

Tominaga M, Caterina MJ, Malmberg AB, Rosen TA, Gilbert H, Skinner K, Raumann BE, Basbaum AI, Julius D (1998) The cloned capsaicin receptor integrates multiple pain-producing stimuli. Neuron 21:531-543.

Trapp S, Aller MI, Wisden W, Gourine AV (2008) A role for TASK-1 (KCNK3) channels in the chemosensory control of breathing. J Neurosci 28:8844-8850.

Valenzano KJ, Grant ER, Wu G, Hachicha M, Schmid L, Tafesse L, Sun Q, Rotshteyn Y, Francis J, Limberis J, Malik S, Whittemore ER, Hodges D (2003) $\mathrm{N}$-(4-tertiarybutylphenyl)-4-(3-chloropyridin-2-yl)tetrahydropyrazine$1(2 H)$-carbox-amide (BCTC), a novel, orally effective vanilloid receptor 1 antagonist with analgesic properties. I. In vitro characterization and pharmacokinetic properties. J Pharmacol Exp Ther 306:377-386.

Waldmann R, Lazdunski M (1998) H(+)-gated cation channels: neuronal acid sensors in the NaC/DEG family of ion channels. Curr Opin Neurobiol 8:418-424.

Wang YY, Chang RB, Waters HN, McKemy DD, Liman ER (2008) The nociceptor ion channel TRPA1 is potentiated and inactivated by permeating calcium ions. J Biol Chem 283:32691-32703.

Young JM, Waters H, Dong C, Fülle HJ, Liman ER (2007) Degeneration of the olfactory guanylyl cyclase D gene during primate evolution. PLoS ONE 2:e884.

Zhang Z, Zhao Z, Margolskee R, Liman E (2007) The transduction channel TRPM5 is gated by intracellular calcium in taste cells. J Neurosci 27:5777-5786.

Ziemann AE, Allen JE, Dahdaleh NS, Drebot II, Coryell MW, Wunsch AM, Lynch CM, Faraci FM, Howard MA 3rd, Welsh MJ, Wemmie JA (2009) The amygdala is a chemosensor that detects carbon dioxide and acidosis to elicit fear behavior. Cell 139:1012-1021. 